\author{
Anna Dąbrowska \\ Wydział Pedagogiczny, Uniwersytet Warszawski \\ E-MAIL: steelon@wp.pl
}

\title{
Równi i równiejsi. Kompetencja komunikacyjna i edukacyjne paradoksy
}

\begin{abstract}
STRESZCZENIE
Kompetencja komunikacyjna to umiejętność stosownego użycia języka w każdej sytuacji komunikacyjnej. Poza kompetencją językową, dzięki której użytkownik potrafi tworzyć poprawne gramatycznie i słownikowo wypowiedzi, obejmuje również wiedzę kulturową odnoszącą się do realiów kręgu cywilizacyjnego, w którym używa się określonego języka. Wysoka kompetencja komunikacyjna jest ważnym składnikiem prezentacji nadawcy komunikatu, wzbogaca i ułatwia kontakty interpersonalne oraz pozwala na pełniejsze korzystanie z wiedzy zgromadzonej w języku przez daną wspólnotę kulturową.

$\mathrm{W}$ artykule podjęto próbę odpowiedzi na pytanie, czym jest kompetencja komunikacyjna oraz przedstawiono przykłady praktyki edukacyjnej, które w wątpliwość podają wspierającą rolę szkoły w rozwijaniu umiejętności językowych dzieci.

SŁOWA KLUCZOWE: kompetencja komunikacyjna, kompetencja językowa, nierówność, komunikacja językowa.
\end{abstract}

Kompetencja komunikacyjna stanowi jedną z kluczowych umiejętności w życiu człowieka. Jej wysoki poziom umożliwia swobodną i skuteczną komunikację w różnorodnych sytuacjach, co daje satysfakcję płynącą ze społecznych kontaktów oraz prowadzi do samodzielnego zdobywania wiedzy.

Jednym z najważniejszych środowisk wychowawczych, w jakim kształtuje się kompetencja komunikacyjna jest dom rodzinny. Sposób komunikowania się rodziców z dzieckiem rzutuje na jego językowe umiejętności i prognozuje dalszy ich rozwój. Środowisko społeczne - w pierwszej kolejności rodzinne - daje dziecku okazję do uczenia się użycia języka. Od jego kapitału społeczno-kulturowego w znacznym stopniu zależą doświadczenia językowe nabyte w pierwszych latach życia dziecka, stanowiące bazę dla kształtowa- 
nia się umiejętności językowych ${ }^{1}$. Szanse na zdobycie różnorodnych, bogatych, wartościowych doświadczeń językowych przez dzieci wywodzące się z odmiennych społecznie środowisk są nierówne. Próg szkoły przekraczają zarówno dzieci, które mają solidne podstawy językowe wyniesione $\mathrm{z}$ domu rodzinnego, jak i te z zaniedbanych środowisk, o niskiej kompetencji komunikacyjnej.

Edukacja w szkole mogłaby stanowić uzupełnienie zróżnicowanej i nie zawsze idealnej sytuacji dla nabywania wysokich umiejętności językowych przez dzieci. Każde dziecko, objęte obowiązkiem szkolnym, ma prawo liczyć na pomoc w kształtowaniu swojej kompetencji komunikacyjnej, która jest kluczem do uczestnictwa w kulturze i życiu społecznym. W szkole dziecko powinno rozwijać umiejętność logicznego, poprawnego i estetycznego wypowiadania się w języku mówionym i pisanym, twórczego konstruowania własnych tekstów, charakteryzujących się spójnością i odpowiednią strukturą, gromadzenia różnorodnych wartościowych doświadczeń językowych, bo dzięki nim będzie w stanie rozumieć sensy metaforyczne, zawarte np. w utworach literackich, a w przyszłości w sposób pełny i skuteczny uczestniczyć w społecznej komunikacji. Realizacja tych zadań przez szkołę dla wielu dzieci mogłaby stanowić szansę na dynamiczny, odkrywający nowe horyzonty, rozwój umiejętności językowych. Mogłaby... ale czy jest?

$\mathrm{W}$ artykule podjęłam próbę odpowiedzi na pytanie, czym jest kompetencja komunikacyjna oraz przedstawiłam przykłady praktyki edukacyjnej, które w wątpliwość podają wspierającą rolę szkoły w rozwijaniu umiejętności językowych dzieci.

Edukacja językowa w szkole paradoksalnie nie sprzyja rozwojowi kompetencji komunikacyjnej uczniów. Umiejętności komunikacyjne kształtowane są głównie poprzez doświadczenia językowe zdobyte poza szkołą, zależne od kapitału społeczno-kulturowego środowiska rodzinnego dziecka. Jednocześnie egzekwowaniu i ocenie podlegają umiejętności językowe uczniów. W tej sytuacji znacznie większe szanse na sukces w szkole mają dzieci wywodzące się z rodzin o wysokim kapitale społeczno-kulturowym, co tworzy wśród uczniów grupy „równych” i uprzywilejowanych „równiejszych”, a w efekcie prowadzi do społecznej reprodukcji.

Por. M. Żytko, Pozwólmy dzieciom mówić i pisać - w kontekście badań językowych trzecioklasistów, CKE, Warszawa 2010, s. 121: „Jak wskazują badania dzieci z rodzin o niskim statusie socjoekonomicznym słyszą do 4 roku o 30 milionów słów mniej niż ich rówieśnicy z rodzin o wyższym statusie. Zasób słownictwa 3-latka z rodziny o wyższym SES jest średnio ponad dwa razy większy niż dziecka z rodziny o niskim SES”, Ch. Wolf, 2009." 


\section{Czym jest kompetencja komunikacyjna}

Pojęcie „kompetencji” odnosi się do zakresu czyjejś wiedzy, umiejętności, odpowiedzialności. Oznacza to, że kompetencja łączy się z określoną dziedziną i charakteryzuje zróżnicowanym poziomem w stosunku do różnych osób.

„Kompetencję komunikacyjną" należałoby zdefiniować w powiązaniu z innym istotnym pojęciem - „kompetencji językowej”. Aby to uczynić, konieczne będzie odniesienie do badań nad językiem i jego nabywaniem, w których wyróżniane są momenty przełomowe związane z pojawieniem się koncepcji ważnych dla kierunku badań. Kierunek ten określić można: od analizy języka poza kontekstem społecznym - np. Ferdynand de Saussure, Noam Chomsky, do badania języka w społecznej komunikacji - np. David Hymes.

W latach pięćdziesiątych XX wieku ukazała się behawiorystyczna praca Burrhusa F. Skinnera, w której autor wyjaśnił proces opanowania języka przez dziecko. W książce zawarto uwagi na temat aktywnej roli dziecka i otoczenia w procesie nabywania języka, nie wyjaśniono jednak genezy mowy. Krytyczną odpowiedź teorii Skinnera sformułował Chomsky. Zaproponował on koncepcję gramatyki generatywno-transformacyjnej i wprowadził do literatury przedmiotu pojęcie „kompetencji językowej”, które jest najważniejszym dla tej koncepcji pojęciem. Według Chomsky’ego dziecko uczy się mówić, ponieważ posiada wrodzoną wiedzę o języku, naturalne zdolności, dzięki którym jest w stanie poznać każdy ludzki język².

Kompetencja językowa, według Chomsky’ego³, to zdolności umożliwiające budowanie nieskończonej liczby zdań ze skończonego repertuaru elementów językowych oraz odróżnianie zdań gramatycznie poprawnych od niepoprawnych. Wiedza ta ma w znacznym stopniu charakter nieuświadomiony. Kompetencja językowa pozwala na korzystanie z języka w sposób kreatywny. Dziecko tworzy wypowiedzi językowe, których nigdy wcześniej nie słyszało. Stosując reguły budowania zdań, może konstruować poprawne wypowiedzi w zupełnie nowych sytuacjach.

Najważniejsze komponenty kompetencji językowej to:

- kreatywność - zdolność tworzenia nieskończonego zbioru zdań ze skończonego zbioru elementów językowych oraz umiejętność konstruowania nowych zdań, spójnych z sytuacjami nowymi dla mówiącego,

L. Smółka, Kompetencja komunikacyjna dzieci sześcio-siedmioletnich, Wydawnictwo Naukowe Akademii Pedagogicznej, Kraków 2004, s. 8.

3 Definicję i komponenty kompetencji językowej podaję za: S. Grabias, Język w zachowaniach społecznych, Wydawnictwo Uniwersytetu Marii Curie-Skłodowskiej, Lublin 1997, s. 34 . 
- gramatyczność - ujawniająca się w procesie budowania zdań poprawność formalna (wynika ze znajomości syntaktycznych reguł języka) oraz poprawność znaczeniowa (wynika ze znajomości leksyki i reguł leksykalnych, mówiących o zdolności łączenia się ze sobą),

- akceptabilność - zdolność rodzimego użytkownika języka do uznawania wypowiedzi za poprawną, tj. zgodną z obowiązującą normą,

- interioryzacja - proces nieuświadomionego opanowywania ojczystego języka.

Kompetencja językowa pozwala zatem na poprawne pod względem formalnym użycie języka.

Podejście generatywno-transformacyjne reprezentowane przez Chomsky’ego spotkało się z krytyką Hymesa - twórcy „etnografii mówienia”, który zaproponował pojęcie „kompetencji komunikacyjnej”. Zauważył on, że zachowania językowe człowieka, poza tym, że podlegają regułom gramatycznym, uwarunkowane są również społecznie i sytuacyjnie ${ }^{4}$. Ich zmienność nie jest dziełem przypadku, ale podlega - podobnie jak gramatyka - pewnym dającym się opisać regułom. Mówieniem, według Hymesa, rządzą zasady odpowiedniości, wykraczające poza gramatykę, których opanowanie stanowi składnik kompetencji osoby mówiącej5. Aby skutecznie się porozumiewać, konieczna jest wiedza użytkownika o kontekście społecznym wypowiedzi. Komunikacja językowa zawsze odnosi się do konkretnej wspólnoty społecznokulturowej. Wiedza o relacji łączącej sytuacje społeczne z zachowaniami językowymi pozwala na odpowiednie użycie języka. Człowiek zdobywa je w toku socjalizacji wraz z uzyskiwaniem życiowych doświadczeń. Umiejętności językowe, czyli znajomość systemu językowego, są więc tylko częścią umiejętno-

${ }_{4}$ Zainteresowanie komunikacyjnym aspektem języka charakterystyczne jest również dla powstałych w tym okresie koncepcji, m.in. teorii aktów mowy J. L. Austina, rozwiniętej przez J. Searle’a i P. Grice’a, funkcjonalno-pragmatycznej teorii uczenia się znaczeń M. A. K. Hallidaya. Przyczynili się oni do rozwoju badań nad kompetencją komunikacyjną. Austin w akcie mowy wyróżnił części: illokucyjną - wyrażającą intencję mówiącego, lokucyjną - stanowiącą część wyrażanego sądu, i perlokucyjną - oznaczającą skutek, jaki dana wypowiedź faktycznie odniosła u odbiorcy. Searle wyróżnił wśród aktów mowy: stwierdzenia, dyrektywy (rozkazy, pytania, prośby), zobowiązania (obietnice, groźby), ekspresje stanów psychicznych i deklaracje (stwarzające nowy stan rzeczy - wyrok w sądzie, akt chrztu czy ślubu). Grice opracował natomiast warunki efektywnej komunikacji, którymi kieruje: zasada rzeczywistości (treść wypowiedzi słuchacz interpretuje jako sąd mający sens i odnoszący się do świata realnego) oraz zasada kooperacji, w ramach której wyróżnił 4 maksymy: ilości (mów tyle, ile wymaga tego aktualny stan dyskursu), jakości (mów to, na co masz dowody i o czego prawdziwości jesteś przekonany), odpowiedniości (mów na temat), sposobu (unikaj dwuznaczności, niejasności, pustosłowia, bądź logiczny), por. I. Kurcz, Psychologia języka i komunikacji, PWN, Warszawa 2000, s. 131-136.

5 D. Hymes, Socjologia i etnografia mówienia, przekł. K. Biskupski, [w:] Język i społeczeństwo, M. Głowiński (red.), Czytelnik, Warszawa 1980, s. 49. 
ści komunikacyjnych. Jak dowodzi lingwista John Lyons ${ }^{6}$, ze względów metodologicznych wyklucza się wiele elementów zachowania językowego, uznając je tym samym za niejęzykowe. Pojęcie kompetencji komunikacyjnej jest szersze i obejmuje pojęcie kompetencji językowej. Stosowna wypowiedź zakłada wiedzę użytkownika o jego społecznym kontekście. Jest to równoważny, choć odrębny aspekt kompetencji.

Kompetencja komunikacyjna to zatem zdolność stosowania w adekwatny sposób wiedzy językowej w sytuacjach komunikacyjnych. Obejmuje zbiór umiejętności pozwalających człowiekowi na podejmowanie interakcji językowych w różnorodnych sytuacjach komunikacyjnych. Składa się na nią wiedza kulturowa odnosząca się do realiów kręgu cywilizacyjnego, w którym używa się określonego języka. Pojedyncze zachowania językowe dokonują się w ramach systemu aktów mowy obowiązujących w danej wspólnocie społecznej, a wiedzę świadomą lub nieuświadamianą o tym systemie, tj. o regułach używania języka w różnych sytuacjach stwarzanych przez tę wspólnotę, nazywa Hymes kompetencją komunikacyjną ${ }^{7}$. Jest ona warunkiem wszelkich społecznych zachowań językowych.

Niezwykle ważną częścią każdej wspólnoty kulturowej jest język, Claude Levi-Strauss określa go jako najdoskonalszy ze wszystkich przejawów porządku kulturowego ${ }^{8}$. Trudno wyobrazić sobie efektywną komunikację językową bez znajomości i respektowania zwyczajów panujących w danej kulturze. Według Małgorzaty Marcjanik największy wpływ na stosowność wypowiedzi ma właśnie obyczaj charakterystyczny dla danej kultury narodowej, dlatego kompetencja komunikacyjna nazywana jest również kompetencją kulturową. Dla zobrazowania autorka podaje ciekawy przykład ${ }^{10}-$ wydarzenie miało miejsce na Uniwersytecie Wrocławskim, kiedy to słuchacze-cudzoziemcy letniego kursu językowego postanowili podziękować i pożegnać swoją lektorkę, przynosząc kwiaty. Okazało się, że wiązanka jest bardzo szczególna. Główki kwiatów - wbite na druciki - ułożone są na gałązkach świerczyny, a całość została przewiązana białą wstążką z napisem „Ostatnie pożegnanie”. Komunikat językowy został poprawnie zbudowany, jednak brak znajomości zwyczaju przynoszenia w Polsce tego typu wiązanek wyłącznie na pogrzeb

\footnotetext{
6 J. Lyons, Semantyka, t. 2, przekł. A. Weinsberg, PWN, Warszawa 1989, s. 188-189.

S. Grabias, op. cit., s. 37.

8 C. Levi-Strauss, Kultura i język, przekł. J. Trznadel, [w:] Antropologia słowa, G. Godlewski, A. Mencwel, R. Sulima (red.), Wydawnictwo Uniwersytetu Warszawskiego, Warszawa 2003, s. 22.

9 M. Marcjanik, Grzeczność w komunikacji językowej, PWN, Warszawa 2013, s. 21.

10 Ibidem.
} 
sprawia, że mamy tu do czynienia z przejawem braku kompetencji komunikacyjnej.

W przeciwieństwie do Chomsky’ego, który w badaniu wychodził od konkretnych użyć języka do tego, co właściwe naturze ludzkiej, Hymes uważał, że należy wyjść od tego, co możliwe w naturze i gramatyce, do tego, co wykonalne i wykonywane. Formułuje zatem 4 pytania, jego zdaniem istotne dla komunikacji ${ }^{11}$ : czy i w jakim stopniu dana rzecz jest (1) Formalnie możliwa, (2) Wykonalna za pomocą dostępnych środków, (3) Stosowna (udana, fortunna), w kontekście, w jakim została użyta i oceniona, (4) Rzeczywiście wykonana i z jakimi następstwami. Istotne w odniesieniu do kompetencji komunikacyjnej jest pytanie trzecie, dotyczące stosowności wypowiedzi językowej. Kompetencja komunikacyjna zakłada zdolność wytwarzania i rozumienia wypowiedzi kontekstowo stosownych. Chodzi o wiedzę, która w konkretnym kontekście użycia języka determinuje określone decyzje fonologiczne, gramatyczne i leksykalne. Rozmówcy powinni:

(1) znać swoją rolę (funkcje wewnątrzkulturowe zinstytucjonalizowane w danym społeczeństwie i uznane przez jego członków) i pozycję społeczną (stanowisko społeczne rozmówców wobec siebie); mówiący zwraca się do swojego rozmówcy - konkretnej osoby obecnej w danej sytuacji (odbiorca może zaakceptować tę rolę i językowo manifestować tę akceptację),

(2) wiedzieć, gdzie i kiedy rozmawiają,

(3) umieć określić stopień oficjalności sytuacji (pewne wypowiedzi mogą się okazać zbyt wykwintne jak na familiarną sytuację, inne zbyt potoczne, a przez to odczuwane jako niestosowne w sytuacji oficjalnej). Wśród zachowań językowych wyróżnić można zjawisko dyglosji, które polega na zależnym od sytuacji użyciu różnych dialektów lub języków w obrębie tej samej społeczności językowej; według Lyonsa ${ }^{12}$ podobne zachowanie językowe można zaobserwować u osób rzekomo jednojęzycznych, które w analogicznej sytuacji przełączają się z jednego stylu na drugi,

(4) wiedzieć, jaka substancja jest odpowiednia w danej sytuacji (niektóre różnice gramatyczne i słownikowe podyktowane substancją mają wpływ na stosowność sytuacyjną wypowiedzi. W wielu kulturach zauważyć można współwystępowanie substancji graficznej z wypowiedziami bardziej oficjalnymi, a fonicznej - z mniej oficjalnymi; odmiany

${ }_{11}$ D. Hymes, op. cit., s. 51
${ }_{12}$ J. Lyons, op. cit., s. 196. 
substancjalne struktury gramatycznej i leksykalnej wykazują wysoki stopień korelacji z różnicami stopnia oficjalności, np. sędzia ogłaszający wyrok używa pod względem leksykalnym i gramatycznym substancji graficznej, chociaż wypowiedź przekazywana jest ustnie, styl wypowiedzi jest oficjalny),

(5) umieć dostosowywać swoje wypowiedzi do tematu (np. ważność tematu może być kryterium wyboru dialektu lub języka podczas konwersacji w zbiorowościach dwujęzycznych). Mówiący dokonuje również wyboru elementów językowych dostosowujących wypowiedź do jego postawy wobec przedmiotu wypowiedzi lub jego zaangażowania emocjonalnego wobec tego przedmiotu,

(6) umieć dostosowywać swoje wypowiedzi do dziedziny lub branży, do której ta sytuacja należy (chodzi tu o zastosowanie odpowiedniego rejestru, czyli konsekwentnej zmienności języka warunkowanej jego użyciem w określonym kontekście społecznym) ${ }^{13}$.

Różnica pomiędzy kompetencją językową a komunikacyjną polega na różnych zakresach wskazanych pojęć. Jak wspomniano, kompetencja komunikacyjna według Hymesa obejmuje cztery komponenty: potencjał systemowy, wykonalność, występowanie i odpowiedniość ${ }^{14}$. Potencjał systemowy jest bliski kompetencji językowej w rozumieniu Chomsky’ego. Umiejętność budowania poprawnych zdań pod względem gramatycznym ujawnia się na poziomie natury, tę umiejętność mogą zdobyć wszystkie zdrowe osoby, bez względu na narodowość czy kulturę. Pozostałe komponenty, nazwane przez Chomsky'ego „wykonaniem”, nie mieszczą się w systemie ${ }^{15}$. Dotyczą one wiedzy, jak budować wypowiedzi, aby osiągnąć swoje cele. Wiedza ta jest zdobywana dzięki pełnieniu różnych ról społecznych i zależy od predyspozycji jednostki oraz jej uczestnictwa w życiu społecznym. Nikt nie jest całkowicie kompetentnym uczestnikiem życia społecznego danej wspólnoty społeczno-kulturowej, jego wiedza dotyczy części kompetencji komunikacyjnej wspólnoty, w której żyje i w której aktywnie uczestniczy.

Według Idy Kurcz ${ }^{16}$ kompetencje związane z językiem wchodzą w pewne zależności, tworzą układ hierarchiczny i wiążą się z ogólną kompetencją symboliczną, tzn. zdolnością do przypisywania znaczenia w rezultacie pro-

3 Ibidem, s. 199.

14 D. Hymes, op. cit., 51.

15 S. Grabias, op. cit., s. 38.

${ }_{16}$ I. Kurcz, Dwujęzyczność a język globalny, [w:] Problemy współczesnej dydaktyki języków obcych, M. Pawlak, M. Derenowski, B. Wolski (red.), Wydawnictwo Uniwersytetu im. Adama Mickiewicza, Poznań - Kalisz 2009, s. 13. 
cesu uczenia się. Obydwie opisywane tu kompetencje - językowa i komunikacyjna - pełnią w umyśle ludzkim odmienne funkcje. Funkcją kompetencji komunikacyjnej jest porozumiewanie się, natomiast językowej - reprezentowanie świata zewnętrznego i wewnętrznego w umyśle, które to reprezentacje stają się z kolei przedmiotem komunikacji międzyludzkiej. Obie kompetencje mają ścisłą lokalizację mózgową, obydwu towarzyszą określone zaburzenia rozwojowe: $\mathrm{z}$ językową łączy się tzw. specyficzne zaburzenie rozwoju językowego - SLI, polegające na trudnościach w opanowaniu fonologii i składni, nie wiążą się z nim jednak żadne ściśle komunikacyjne problemy, natomiast zaburzeniem kompetencji komunikacyjnej jest autyzm - występują tu kłopoty zarówno z rozumieniem intencji komunikacyjnych innych osób, jak i z właściwym wyrażeniem własnych motywów i przekonań. Kurcz ${ }^{17}$ wyjaśnia:

Rozwój obu kompetencji przebiega przez pewne stadia, które charakteryzują wszelkie zachowania oparte na wrodzonych zadatkach, czyli biologicznie uwarunkowanych. Przyjmuje się, że dla kompetencji językowej takie podłoże biologiczne stanowi tzw. gramatyka uniwersalna (UG) (Chomsky, (1965/1980), nazywana też gramatyką naturalną (Steinberg i Scialini 2006) lub gramatyką kognitywną (Langacker 1998). Umożliwia ona przyswojenie sobie w sposób - w dużej mierze - automatyczny jedynego dwupoziomowego kodu naturalnego, jakim jest dowolny język ludzki. Z kolei zdaniem wielu psychologów podłoże biologiczne kompetencji komunikacyjnej stanowi tzw. Teoria umysłu /TU/, czyli wrodzona intuicyjna zdolność do odczytywania stanów umysłowych (przekonań, intencji) własnych czy innych osobników (Premack i Woodruff 1978) ${ }^{18}$.

Dzięki kompetencji komunikacyjnej nadawca może określić sytuację i zastosować taką wersję języka wypowiedzi, która będzie w danej sytuacji najbardziej odpowiednia. Oczywiście jest to możliwe tylko wówczas, gdy jego repertuar socjolektalny obejmuje więcej niż jedną odmianę języka, np. osoba posługująca się wyłącznie gwarą nie może dostosować się do zmieniającej się sytuacji komunikacyjnej. Zarówno w sytuacjach urzędowych, jak i familijnych będzie posługiwać się tą samą odmianą języka ${ }^{19}$. Kompetencja komu-

17 I. Kurcz, op. cit., s. 14. Szczególnie ciekawy przykład relacji zachodzących pomiędzy kompetencją językową a komunikacyjną podaje Kurcz, powołując się na przypadek autystycznego chłopca, badanego przez brytyjskich lingwistów: Neila Smitha i Ianthi-Marię Tsimpli (1995), który miał niezwykłe zdolności językowe. Czas swój poświęcał na naukę języków obcych, znał ich 16, ale w żadnym nie umiał się w pełni komunikować - nie rozumiał dowcipów, metafor, pośrednich aktów mowy.

18 Podaję za ibidem, s. 14.

19 Podczas badań, które prowadziłam w 2002 r., związanych z językiem młodzieży w środowisku wiejskim, rozmawiałam z gimnazjalistami, którzy - wyczuwając oficjalność sytuacji komunikacyjnej - starali się przyjąć możliwie oficjalny (poprawny, bogaty) język. Jednak w wielu przypadkach nie udawało się to. Wielu z nich nie dysponowało takim wariantem języka i pomimo swoich intencji, używali swobodnej, slangowej, niekiedy gwaro- 
nikacyjna ułatwia zrozumienie prawdziwych intencji nadawcy danej wypowiedzi. Podam najprostszy przykład - zdanie: „Czy mógłby Pan powiedzieć, która jest godzina?", gramatycznie jest pytaniem, które wymagałoby odpowiedzi typu: „tak/nie”. W gruncie rzeczy jednak nim nie jest, mimo że na to wskazuje struktura wypowiedzi, ale jest prośbą. Podobnie i stwierdzenie: „Jak tu duszno!”, nie jest informacją, ale najczęściej prośbą o otworzenie okna. Te proste przykłady pokazują, że kompetencja komunikacyjna jest niezbędna, aby odczytać intencje nadawcy nawet podstawowych komunikatów. Kompetencja komunikacyjna obejmuje następujące umiejętności: korzystanie z wersji zarówno mówionej, jak i pisanej języka, swobodne posługiwanie się językiem potocznym i oficjalnym, bogactwo słownictwa, dostosowanie sposobu komunikowania do sytuacji komunikacyjnej, odczytywanie intencji nadawcy komunikatu, odczytywanie tekstów kultury. Nabycie tych umiejętności ułatwia pełne uczestnictwo w komunikacji społecznej.

Poza respektowaniem reguł językowych efektywna komunikacja wymaga uwzględnienia cech sytuacyjnych. Kompetencja komunikacyjna według Hymesa obejmuje

zdolność używania przez człowieka wszystkich systemów semiotycznych dostępnych dla członka danej wspólnoty społeczno-kulturowej. Składają się na nią m.in. - rola i pozycja społeczna rozmówców, zjawiska para lingwistyczne, np. składniki różnych kodów pozawerbalnych (łącznie z operowaniem przestrzenią), warunki stosowności wypowiedzi, takie jak miejsce i czas czy system deiktyczny, a także umiejętności określenia stopnia oficjalności sytuacji (od sztywnego do familiarnego), umiejętności wyboru substancji dla danej sytuacji, dostosowania swojej wypowiedzi do tematu, a także do branży i dziedziny, której ta sytuacja doty$\mathrm{czy}^{20}$.

Zachowania językowe zależą więc od pewnych składników interakcji, które kształtują postać wypowiedzi językowych. Należą do nich: układ sytuacyjny (miejsce - w sensie fizycznym, społecznym i psychologicznym; uczestnicy - role uczestników interakcji wokreślonym układzie sytuacyjnym, tematy i cele (tematy konwersacji podlegają zwyczajom kulturowym) ${ }^{21}$.

Wśród nich istotne znaczenie ma układ społecznych ról językowych. Chodzi o: role trwałe (w kontaktach oficjalnych: rangi równorzędne i nierówno-

wej, odmiany polszczyzny. Tylko wysoka kompetencja komunikacyjna, o której świadczy znajomość i umiejętność użycia zarówno swobodnej, potocznej, jak i starannej, oficjalnej polszczyzny, pozwala na umiejętne przechodzenie z jednej wersji do drugiej.

2o Podaję za: G. Sawicka, Konwencja a kompetencja komunikacyjna, [w:] Język w komunikacji (1), G. Habrajska (red.), Wydawnictwo Wyższej Szkoły Humanistyczno-Ekonomicznej w Łodzi, Łódź 2001, s. 118.

${ }^{21} \quad$ I. Kurcz, Psychologia języka i komunikacji..., s. 140. 
rzędne uczestników interakcji, w kontaktach nieoficjalnych: rangi równorzędne i nierównorzędne uczestników interakcji), role nietrwałe (w kontaktach oficjalnych: rangi równorzędne i nierównorzędne uczestników interakcji, w kontaktach nieoficjalnych: rangi równorzędne i nierównorzędne uczestników interakcji), układ sytuacyjny (miejsce, czas rozmowy, liczba rozmówców, kanał przekazu i temat wypowiedzi) oraz cel wypowiedzi (intencje mówiącego - funkcje: emocjonalne, modalne, działania). Odnosząc się do uwarunkowania związanego z układem ról uczestników interakcji, Grabias zauważa, że choć proces opanowywania języka przez dziecko jest długi i skomplikowany, to badania wskazują, że dzieci 5-, 6-letnie, które w zasadzie opanowały już system językowy, mają również świadomość następujących ról:

- dziecko - dziecko (znajome, obce),

- dziecko - dorosły (rodzice, znajomi, obcy)22.

Oczywiste jest, że do tego wieku większość interakcji społecznych zachodzi w domu rodzinnym, co oznacza, że powyższą orientację w zachowaniach językowych związanych z układem ról zdobywa dziecko na podstawie domowych doświadczeń językowych, zależnych od kapitału społeczno-kulturowego tegoż środowiska. I tu rodzi się pytanie, jak w tę dziecięcą sprawność językową wpisuje się edukacja szkolna? W jaki sposób szkoła przyczynia się do wzbogacania doświadczeń językowych dziecka, niezbędnych dla kształtowania się i rozwoju jego kompetencji komunikacyjnej? Czy komunikacja na lekcji rzeczywiście sprzyja kształtowaniu się tej sprawności, zwłaszcza w odniesieniu do dzieci pochodzących z rodzin o niskim kapitale społeczno-kulturowym?

Zgodnie z teorią interakcyjnej intencjonalności dziecko zdobywa umiejętności językowe w interakcjach społecznych ${ }^{23}$. Kompetencja komunikacyjna kształtuje się w toku użycia języka. Dziecko w tym procesie pełni rolę, którą można określić jako rola „psychologa” oraz „budowniczego języka”. Podczas komunikacji dziecko uczy się odczytywania intencji w sytuacji komunikacyjnej oraz wychwytywania wzorów w mowie otoczenia i budowania na tej podstawie systemu językowego. W ten sposób następuje rozwój językowy, polegający na stopniowym, uporządkowanym i kompleksowym opanowywaniu języka, dla którego bezpośrednią motywację stanowi potrzeba komunikowania własnych myśli i bycia zrozumianym przez otoczenie.

Według modelu interakcjonistycznego rozwój językowy następuje dzięki różnorodnym formom korzystania $\mathrm{z}$ komunikacji językowej przez dzie-

22 S. Grabias, op. cit., s. 281.

${ }^{23}$ Psychologia języka dziecka. Osiągnięcia, nowe perspektywy, B. Bokus, G. W. Shugar (red.), GWP, Gdańsk 2007, s. 26-27. 
cko: mówienie, pisanie, czytanie, a także dzięki stosowaniu języka w różnorodnych sytuacjach komunikacyjnych - w odmiennych kontekstach, z myślą o różnych celach, tematyce i odbiorcach. Kompetencja komunikacyjna kształtuje się zarówno podczas rozmów dziecka z dorosłymi, jak i z rówieśnikami, np. we współpracy podczas rozwiązywania problemów, poszukiwaniu informacji i podejmowaniu działań twórczych.

Doskonałą okazję nabywania tej umiejętności przez dzieci i młodzież mogłaby stanowić edukacja szkolna. Od pewnego wieku dziecko ma przecież bardzo wyraźne poczucie odmiennego sposobu komunikowania się w sytuacji oficjalnej - z nauczycielem podczas lekcji oraz z rówieśnikami podczas przerwy, ten język Halina Zgółkowa utożsamia z gwarą uczniowską ${ }^{24}$. Jak wskazuje Małgorzata Żytko, doskonalenie kompetencji komunikacyjnej w toku szkolnej edukacji jest szczególnie ważne w przypadku dzieci z zaniedbanych kulturowo i edukacyjnie środowisk. Konieczne jest jednak spełnienie określonych warunków: dzieci muszą mieć szansę eksperymentowania i używania języka w różnych sytuacjach, konstruowania tej umiejętności w drodze interakcji z nauczycielem i kolegami ${ }^{25}$. Podczas lekcji należałoby stworzyć okazję, by kształcić umiejętność stosownej dyskusji, odpowiedniej argumentacji, stawiania tezy i jej obrony. Pozwolę tu sobie przywołać nieco może nostalgiczny obrazek opisujący praktykę kształcenia tych umiejętności podczas nauki w Gimnazjum i Liceum im. Księcia Józefa Poniatowskiego w trudnych czasach, tuż przed wybuchem drugiej wojny światowej, opisany w książce, która jest wywiadem-rzeką z prof. Witoldem Kieżunem.

Była to swego rodzaju realizacja często powtarzanego przez nas marzenia Poety z „Wesela” Wyspiańskiego: „tak by się nam serce śmiało do ogromnych, wielkich rzeczy". Nasze gorące debaty na lekcjach (mieliśmy codziennie dwie godziny zajęć z języka polskiego, podobnie z historii) i w Klubie Dyskusyjnym były swoistym poszukiwaniem tych „ogromnych, wielkich rzeczy”. Tam właśnie, po powrocie z wycieczki do Francji i Niemiec, jako piętnastoletni uczeń pierwszej klasy Liceum wygłosiłem referat pod tytułem „Europa po «Mein Kampf»”, rysujący grozę imperialnych, antypolskich i antysemickich tendencji nazizmu. [...] Idea, którą później nazwałem ekumenizmem intelektualnym, stała się podstawą ideową wspomnianego Klubu Dyskusyjnego ${ }^{26}$.

Prawdopodobnie prof. Kieżun miał szczęście jako młodzieniec kształcić się pod opieką wyjątkowego nauczyciela, o którym wypowiada się w superla-

24 Nowy słownik gwary uczniowskiej, H. Zgółkowa (red.), Wydawnictwo Europa, Wrocław 2004, s. 5.

25 M. Żytko, op. cit., s. 120.

${ }^{26}$ Magdulka i cały świat. Rozmowa biograficzna $z$ Witoldem Kieżunem przeprowadzona przez Roberta Jarockiego, Iskry, Warszawa 2013, s. 58-59. 
tywach, jednak gdy czytamy ten opis, rodzi się pytanie, czy we współczesnej szkole jest czas i płaszczyzna do tak pieczołowitego pochylenia się nad kształtowaniem kompetencji komunikacyjnej uczniów? W jaki sposób edukacja szkolna wspiera, niezależnie od umiejętności i doświadczeń językowych nabytych w domu przez dziecko, tę kluczową w życiu społecznym umiejętność?

\section{Edukacyjne paradoksy}

Paradoks to „twierdzenie zaskakująco sprzeczne z przyjętym powszechnie mniemaniem, często ujęte $\mathrm{w}$ formę aforyzmu”. To także „rozumowanie pozornie oczywiste, ale wskutek zawartego w nim błędu prowadzące do wniosków jawnie sprzecznych ze sobą lub z uprzednio przyjętymi założeniami”. Paradoksalną określana jest „sytuacja pozornie niemożliwa, w której współistnieją dwa całkowicie różne lub wykluczające się fakty" ${ }^{27}$.

Założenia i praktyka edukacyjna odnosząca się do kształcenia językowego dzieci sprawia wrażenie właśnie sytuacji „pozornie niemożliwej”. Według Podstawy PROGRAMOWEJ umiejętność komunikowania się w języku ojczystym - odbioru i tworzenia wypowiedzi - zarówno w mowie, jak i w piśmie, jest jedną z najważniejszych umiejętności zdobywanych przez ucznia w trakcie kształcenia w szkole podstawowej, a doskonalenie umiejętności posługiwania się językiem polskim, w tym dbałość o wzbogacanie zasobu słownictwa ucznia, należy do obowiązków każdego nauczyciela ${ }^{28}$.

Rozwojowi kompetencji komunikacyjnych sprzyja uczestnictwo uczniów w różnorodnych sytuacjach komunikacyjnych, w których pełni on aktywną i twórczą rolę. Tymczasem z badań prowadzonych przez Żytko wynika, że dzieci na etapie edukacji wczesnoszkolnej w bardzo znikomym stopniu taką okazję otrzymują.

Sposób komunikowania się nauczyciela z uczniami cechuje dyrektywność, narzucanie przez nauczyciela ,jedynie słusznego" punktu widzenia, brak możliwości formułowania przez uczniów dłuższych wypowiedzi i prezentowania własnego zdania. [...] dominuje wymiana komunikatów inicjowanych przez nauczyciela, zwykle z całą klasą lub pojedynczymi uczniami w schemacie: nauczyciel zadaje pytanie - uczeń udziela odpowiedzi. Pytania mają w większości charakter zamknięty i wymagają jednoznacznych odpowiedzi, na które nakierowuje dzieci nauczyciel. Gdy nie udaje mu się uzyskać satysfakcjonującej reakcji ze strony uczniów, sam odpowiada na zadawane przez siebie pytania. Często można zaobserwować rodzaj gry prowadzonej przez nauczyciela z dziećmi, której nazwa mogłaby być następująca: „zgadnijcie, co mam na myśli”. Rzadko podczas zajęć

${ }_{27}$ Słownik języka polskiego, PWN, http://sjp.pwn.pl/ [19.07.2015].

${ }_{28}$ Podstawa programowa z komentarzami, t. 2, Język polski w szkole podstawowej, gimnazjum i liceum, s. 15-16, http://www.bc.ore.edu.pl/Content/232/Tom +2+J\%C4\%99zyk+polski+w+s zkole+podstawowej\%2C+gimnazjum+i+liceum.pdf [19.07.2015]. 
szkolnych pojawiają się interakcje inicjowane przez uczniów, pytania kierowane od ucznia do nauczyciela lub rówieśników, wymiana opinii między uczniami. Nauczyciel nie wspiera aktywności uczniów, nie zachęca ich do samodzielnego działania, nie inspiruje do poszukiwań, nie stawia wyzwań poznawczych ${ }^{29}$.

Autorka dowodzi, że uczeń w szkole ma ograniczone możliwości uczestniczenia w różnorodnych sytuacjach komunikacyjnych. Podczas lekcji nie prowadzi naturalnej rozmowy z nauczycielem i rówieśnikami, ale porozumiewa się w sztuczny sposób, co zaburza dziecięcą kompetencję komunikacyjną. Język w klasie szkolnej służy raczej jako narzędzie egzekwowania wiedzy niż komunikacji z innymi. Dziecko przekraczające próg szkoły w wieku 7 lub 6 lat (po reformie) posiada już pewne wzory zachowań językowych w relacjach dziecko - dorosły, dziecko - dziecko. Sztuczność komunikacji w klasie szkolnej stoi w sprzeczności z dotychczasowymi doświadczeniami dziecka. Nie chodzi o dowiedzenie się czegoś nowego, ale o wypowiedzenie znanego komunikatu - w taki sposób, żeby nauczyciel był zadowolony.

Niepokojąco przedstawiają się również wyniki dotyczące ilości czasu poświęconego wybranym rodzajom aktywności ucznia na zajęciach edukacji językowej ${ }^{30}$. Łącznie aż 84,1\% czasu zajęć zajmuje: słuchanie nauczyciela, czynności organizacyjne oraz sprawdzanie wiedzy. Są to czynności, które w znikomym stopniu aktywizują dzieci językowo. Oznacza to, że bardzo niewiele czasu pozostaje na lekcji na zdobywanie przez ucznia różnorodnych i bogatych językowych doświadczeń, sprzyjających rozwojowi kompetencji komunikacyjnej. W związku z tym dziecko w szkole posługuje się językiem w ograniczonym zakresie, komunikacja z nauczycielem sprowadza się zwykle do pytania i oczekiwania konkretnej odpowiedzi od ucznia. Uczeń rzadko doświadcza zachęty ze strony nauczyciela do aktywności językowej. Na etapie edukacji wczesnoszkolnej rzadko ma okazję do dyskusji, wymiany poglądów.

Sprawność w komunikowaniu się z innymi sprzyja podejmowaniu przez dziecko społecznych interakcji, prowadzi do samodzielnego zdobywania wie-

29 M. Żytko, op. cit., s. 22.

30 Rozkład procentowy czasu poświęconego wybranym rodzajom aktywności ucznia na zajęciach edukacji językowej przedstawia się w następujący sposób: udział w czynnościach organizacyjnych $-8,1$, udział w procesie sprawdzania wiedzy - 49,1, słuchanie nauczyciela, który mówi, czyta, prowadzi pogadankę - 26,9, dyskusja i rozmowa z nauczycielem i kolegami - 2,1, aktywność twórcza/badawcza - 5,1, udział w grach i zabawach dydaktycznych - o,1; czas trwania zajęć (w minutach) 2,053, por. ibidem, s. 34 . 
dzy przez dziecko, tymczasem - w przeciwieństwie do czytania i pisania mówienie ma w szkole niską rangę. Jak wskazuje Dorota Klus-Stańska ${ }^{31}$,

Traktowane jest wyłącznie jako nośnik informacji, pozwalający kontrolować przebieg lekcji. Namysł nauczyciela nad jakością mówienia rzadko lub nawet nigdy nie dotyczy pedagogicznych starań o doświadczanie przez uczniów komunikowania się z drugim człowiekiem, a obowiązujące reguły wyrażania myśli często polegają na deformowaniu żywej mowy przez narzucanie jej form typowych dla języka pisanego. Najczęściej polega to na nadużywaniu komunikacji, której wyłącznym celem jest ustalenie zdań do zapisania na tablicy, wypowiedziach nauczyciela nieświadomie formułowanych w stylistyce notatki oraz na wymuszaniu na uczniach nietypowej dla żywej mowy hiperstaranności na przykład przez wymaganie udzielania odpowiedzi koniecznie pełnym zdaniem. Wszystko to redukuje edukację związaną z mówieniem, narażając uczniów na nawyk nadawania swoim wypowiedziom nienaturalnych form, zakłócających werbalne porozumiewanie się.

$\mathrm{Na}$ wczesnym etapie edukacji, gdzie spodziewać by się można szczególnego wsparcia szkoły w rozwijaniu kompetencji komunikacyjnej dzieci, paradoksalnie organizacja procesu kształcenia utrudnia zdobywanie różnorodnych i wartościowych doświadczeń językowych, blokując tym samym, a niekiedy zaburzając językową sprawność sytuacyjną dzieci.

Szkoła jest miejscem, w którym poza przekazywaniem wiedzy przekazuje się jednocześnie pewien sposób komunikowania się. Badacz kodów komunikowania się, Basil Bernstein ${ }^{32}$, zakładał, że transmisja wiedzy w szkole dokonuje się za pomocą rozwiniętego kodu socjolingwistycznego, ponieważ komunikaty nie odnoszą się do najbliższego kontekstu sytuacyjnego. Według Hymesa, formy narracji odwołujące się do własnych doświadczeń są w szkole uznane za niewłaściwe i „nienaukowe”, a uczniowie, którzy się nimi posługują mogą być uznani za mniej sprawnych poznawczo. Język podręczników szkolnych stanowiący część edukacyjnej rzeczywistości językowej nie jest naturalnym, pojawiającym się w codziennej komunikacji sposobem porozumiewania się. Teodozja Rittel ${ }^{33}$ uznaje go za przykład nadkompetencji. Język ten może się wydawać dla pewnych grup uczniów językiem obcym. Brak zrozumienia to w pewnym sensie brak dostępu do prezentowanych treści. I znów

${ }_{31}$ D. Klus-Stańska, M. Nowicka, Sensy i bezsensy edukacji wczesnoszkolnej, WSiP, Warszawa 2005, s. 78.

32 Za: J. Bielecka-Prus, Transmisja kultury w rodzinie i w szkole. Teoria Basila Bernsteina, PWN, Warszawa 2010, s. 192. Według Bernsteina kod ograniczony lub rozwinięty wykorzystywany podczas komunikacji z dzieckiem w domu rodzinnym w dużej mierze określa i prognozuje jego umiejętności językowe, por. B. Bernstein, Odtwarzanie kultury, przekł. Z. Bokszański, A. Piotrowski, PIW, Warszawa 1990.

33 J. Bielecka-Prus, op. cit., s. 192. 
kluczowe znaczenie ma przygotowanie dziecka, poprzez pozaszkolne, najczęściej rodzinne, kształtowanie kompetencji komunikacyjnej, umożliwiające odbiór prezentowanych treści.

Badania prowadzone w klasie szkolnej ${ }^{34}$ wykazały, że dziecko jest najczęściej milczącym obserwatorem i słuchaczem. Nauczyciel ma centralną pozycję w procesie komunikacji, on inicjuje i ocenia jej przebieg, często preferując styl autorytarny. Komunikacja toczy się według utartych schematów, a aktywność uczniów jest stłumiona. Według Ewy Bochno, nauczyciele w czasie lekcji posługują się kodem quasi-rozwiniętym, który nie sprzyja rozwojowi poznawczemu dziecka, ogranicza kreatywność uczniów i uniemożliwia autentyczne podmiotowe relacje oparte na dialogu i wzajemnym zrozumieniu. Relacja nauczyciel - uczeń jest podobna w swobodnych kontaktach. Nauczyciel decyduje o czasie, miejscu, temacie komunikacji. W sytuacji pozalekcyjnej rola nauczyciela względem ucznia, podobnie jak to się dzieje podczas lekcji, jest dominująca ${ }^{35}$.

W starszych klasach szkoły podstawowej autorytarny styl komunikacji podczas lekcji jeszcze bardziej się nasila. Reakcją uczniów na ten oficjalny i nienaturalny język jest język przerwy, który Zgółkowa utożsamia z gwarą uczniowską. Jest on barwny, ekspansywny, często wulgarny. Wiele w nim emocjonalności i humoru. Według Zgółkowej ${ }^{36}$, często stosowana przez młodzież gwara uczniowska jest zauważana przez nauczycieli. Wątpi jednak, aby była przedmiotem ich refleksji. Zwłaszcza lekcje języka ojczystego byłyby dobrą okazją do analizy zjawisk językowych charakterystycznych dla uczniowskiej gwary. Ponadto mogłyby się okazać zajęciami, które spotkałyby się z dużym zainteresowaniem uczniów. Mowa byłaby przecież o zachowaniach językowych ich samych. Zgółkowa widzi przejaw panowania w tym zakresie swoistej hipokryzji: wszyscy - i nauczyciele, i uczniowie - wiedzą, że gwarą uczniowską młodzi ludzie posługują się poza lekcjami i poza szkołą, ale nie stanie się ona tematem zajęć ${ }^{37}$. Trzeba przecież uczyć polszczyzny pięknej -

34 Badania takie m.in. prowadziły niezależnie: E. Putkiewicz, E. Bochno, T. Rittel, por. ibidem, s. 192-193.

35 E. Bochno, Rozmowa jako metoda oddziaływania wychowawczego, Oficyna Wydawnicza Impuls, Kraków 2004, s. 175.

${ }^{36}$ H. Zgółkowa, Gwara uczniowska (szkolna) w poszukiwaniu inspiracji, [w:] Oblicza polszczyzny, A. Markowski, R. Pawelec (red.), Narodowe Centrum Kultury, Warszawa 2012, s. 89.

37 Zgółkowa dowodzi, że nauczyciele nie tylko wiedzą o tym, że uczniowie posługują się gwarą szkolną, ale sami z niej niejednokrotnie korzystają, nawet w oficjalnej szkolnej komunikacji. Podaje przykłady wpisów do dziennika, dokonywanych przez nauczycieli z użyciem gwary uczniowskiej: „olewa nauczyciela”, "grozi nauczycielce, że poda ją do 
odświętnej - nie interesuje nas polszczyzna szkolnej i pozaszkolnej codzienności.

$\mathrm{Na}$ trudności związane z rozwijaniem umiejętności językowych uczniów na kolejnych etapach kształcenia zwraca również uwagę T. Zgółka ${ }^{38}$. Wyraża niepokój związany z miejscem nauki języka ojczystego i nauki o języku w polskiej szkole, zwłaszcza na poziomie gimnazjum i liceum. Polonista jest utożsamiany z literaturoznawcą, zaś w szkole realizowany jest dziewiętnastowieczny model filologii obejmujący analizę tekstu literackiego ${ }^{39}$. Bardzo często odbywa się pozorne łączenie nauki o języku z nauką literatury; poprzez bardzo nierówne proporcje godzin przeznaczonych na naukę języka jest to trudne do realizacji.

Tadeusz Zgółka wyjaśnia:

Implicite zakłada się, że dziecko przychodzące do szkoły dysponuje już wystarczającymi umiejętnościami w zakresie posługiwania się językiem ojczystym. Wraz z kolejnymi poziomami edukacyjnymi przekonanie to staje się silniejsze, co doprowadza do marginalizacji tego komponentu kształcenia na IV, licealnym, poziomie edukacyjnym ${ }^{40}$.

Autor dochodzi do smutnego i zaskakującego wniosku - w kwestii nabywania sprawności i umiejętności językowych, w kontekście europejskim, za sprawą europejskiego systemu opisu kształcenia językowego obowiązują standardy wymagań egzaminacyjnych (nie są to standardy nauczania), opracowanych dla poszczególnych poziomów biegłości w posługiwaniu się językiem obcym. Poziom najwyższy - C2 - jest identyczny ze sposobem posługiwania się językiem przez rodzimego użytkownika. Polscy uczniowie, obecnie stosunkowo często ubiegający się o certyfikaty znajomości zwłaszcza języka angielskiego, wiedzą, że stawiane im wymagania koncentrują się na

sądu za to, że zorała mu psyche, każąc przesiąść się do innej ławki”, „uczennica nazwała mnie starą rurą", por. ibidem, s. 88.

${ }_{38}$ T. Zgółka, Dydaktyka szkolna języka polskiego jako ojczystego w perspektywie europejskiej, [w:] Oblicza polszczyzny..., s. 73.

39 O tym, jak ta analiza tekstów - na przykładzie analizy tekstów staropolskich - wygląda w praktyce szkolnej, w interesujący, ale niezbyt optymistyczny sposób pisze M. Ratajczak. Autor dowodzi, że uczniowie pierwszej klasy liceum w niewielkim stopniu opanowali umiejętności, które zakłada Podstawa programowa dla gimnazjum. Licealiści, wbrew temu, co zakłada Podstawa..., nie potrafią sprawnie budować wypowiedzi mówionych i pisanych, operować strukturami gramatycznymi odpowiednio do sytuacji i kontekstu wypowiedzi, nie mają świadomości wpływu użytych form na klarowność i spójność wypowiedzi. Wobec powyższego, nauczycielom języka ojczystego w liceum trudno jest realizować założenia programowe dotyczące rozwijania uczniowskiej kompetencji językowo-komunikacyjnej, por. M. Ratajczak, (Nie)kompetencje językowe, [w:] Oblicza polszczyzny..., s. 64-71.

40 T. Zgółka, op. cit., s. 74. 
odmianie standardowej (a nie potocznej). W przypadku języka obcego podczas nauki nabywają więc kompetencji komunikacyjnej w wersji standardowej tegoż języka, natomiast szkolna nauka polszczyzny odbiega od praktyk komunikacyjnych. Potrzebny jest oczywiście opis współczesnej polszczyzny standardowej, ale

standard powinien być dopasowany do rzeczywistości współczesnej polszczyzny, a nie oparty na wyrafinowanej normie wzorowanej na przykład na polszczyźnie literackiej w wersji klasycznego stylu wysokiego (do czego też dąży czasem polska szkoła) ${ }^{41}$.

Kolejny paradoks edukacyjny można by nazwać „testomanią szkolną”. Wszechobecność testów jako uprzywilejowanego sposobu sprawdzania wiedzy z zakresu nauk humanistycznych, zarówno w wewnętrznej praktyce szkolnej, jak i podczas egzaminów zewnętrznych, rodzi pewne konsekwencje. Nauczyciele, rozliczani z wyników osiąganych przez swoich podopiecznych, zdają sobie sprawę, że sposób egzaminowania trzeba wziąć pod uwagę w sposobie nauczania. Efekt? Nauka „pod test”. Test jest szybki do sprawdzenia. To fakt. Daje ponadto poczucie otrzymania konkretnej i pewnej informacji o wiedzy ucznia, w przypadku testu nie może być mowy o nierównym, a więc niesprawiedliwym potraktowaniu egzaminowanych. Powyższe konstatacje budzą jednak wątpliwość, czy nie są to złudne walory i jaki jest ich koszt. Diane Ravitch twierdzi: „Póki w szkołach będą testy, nie da się obudzić w uczniach ufności, ciekawości i kreatywności"ł2. Wydawać by się mogło, że wysokie wyniki osiągane przez uczniów można uznać za sukces. Krytykując jednak tego typu rozwiązania, autorka powołuje się na przykład kraju, gdzie na wydzielonym obszarze powstały niezwykle kosztowne specjalne instytucje, których celem jest przygotowanie do zdania egzaminów testowych, i są w tym bardzo skuteczne. Dzieci umieszczone w tych instytucjach edukacyjnych od wczesnego ranka do późnych godzin wieczornych zajmują się głównie rozwiązywaniem wszelkiego typu testów i w końcu osiągają sukces, będący wynikiem ciężkiej (ale czy potrzebnej?) pracy. Autorka artykułu pisze: „Chiny mają najlepszy i najgorszy system kształcenia, najlepszy, bo gwarantuje najwyższe wyniki testów, najgorszy, bo wyniki osiągane są kosztem kreatywności i indywidualizmu”3.

\footnotetext{
${ }^{41} \quad$ Ibidem, s. 77.

42 D. Ravitch, Testy precz ze szkół!, „Gazeta Wyborcza” z 6-7 grudnia 2014 r.

43 Ibidem.
} 
Ewaluacja wiedzy w postaci testu zwykle wiąże się z nauką „pod klucz”. Koncentracja w naukach humanistycznych na tego typu nauczaniu może spowodować zaniedbania w praktykowaniu pisania własnych tekstów. I tu wrócę do przywołanych wcześniej wspomnień prof. Kieżuna: wiele lat temu w polskiej szkole do kształtowania umiejętności tworzenia rozbudowanych form wypowiedzi, np. pisania eseju, przykładano dużą wagę. Umiejętności językowe zdobywa się w praktyce, która pozwala ukształtować swój własny styl i nabrać wprawy, a obciążenie nauki języka ojczystego szkolną testomanią ogranicza możliwości ich rozwoju.

Na skutki nie trzeba długo czekać. Nie chcę dołączać do grona osób utyskujących na powszechność uczniowskich błędów językowych, one są najprostszym do sprawdzenia przejawem braków w kompetencji komunikacyjnej. O wiele groźniejsze wydają się trudności uczniów w kreowaniu własnych tekstów, a jest to jedna z zasadniczych części kompetencji komunikacyjnej. Tekst pisany, w przeciwieństwie do wypowiedzi mówionej, charakteryzuje się pewnymi swoistymi cechami - oderwaniem od kontekstu sytuacyjnego, umiejętnością zawarcia treści uogólnionych, spójnością i odpowiednią strukturą. Jako że korzystanie z języka ma związek z myśleniem człowieka, nabycie umiejętności konstruowania pisanego tekstu zmienia również sposób prowadzenia toku myślowego. Poczynając od gromadzenia obrazów nanizanych niczym paciorki na sznurek, redundancji treści, powtórzeń w wypowiedzi, charakterystycznych dla przedpiśmiennego sposobu myślenia, użytkownik opanowuje konstrukcję podrzędności, obejmuje myślą szerszy układ treści, co z kolei wiąże się z piśmiennością ${ }^{44}$. Tymczasem, przykładowo, uczniowie klas szóstych w ciągu ostatnich lat w ogólnopolskich sprawdzianach szóstoklasisty regularnie wypadają najsłabiej w kategorii: tworzenie własnych tekstów ${ }^{45}$ (osiągają wyniki od $45 \%$ punktów w 2011/2012 do 54\% w 2012/2013, jest to najniższy wynik w zakresie wiedzy i umiejętności z języka polskiego). Oczywiście, przeważająca część sprawdzanej wiedzy w zakresie języka ojczystego odbywa się za pomocą testu. Sytuacja nie wygląda lepiej w przypadku egzaminów uczniów kończących gimnazjum, a więc jednolitą obowiązkową edukację. Według Centralnej Komisji Egzaminacyjnej dla gimnazjalistów w 2014 roku „zadania badające funkcjonalne, świadome posługiwanie się językiem [...] okazały się najtrudniejsze"ł6.

44 Szeroko pisał o tym Ong, por. W. J. Ong, Oralność i piśmienność. Słowo poddane technologii, przekł. J. Japola, WUW, Warszawa 2011.

45 http://www.operon.pl/wyniki_ogolnopolskie_probny_sprawdzian_szostoklasisty [24.04.2015].

46 http://cke.edu.pl/images/files/gimnazjum/wstepna_informacja_o_wynikach/ 2014/20140616_GIMNAZJUM_Wst\%C4\%99pna_informacja_o_wynikach_2014r.pdf, s. 9 [24.04.2015]. 
Po egzaminach gimnazjalnych w 2015 roku, uczniowie zapytani przez dziennikarzy o wrażenia po egzaminie wyrażali zadowolenie $\mathrm{z}$ tego powodu, że w części sprawdzającej umiejętność tworzenia własnego tekstu autorzy zrezygnowali z rozprawki, której się spodziewano, na korzyść opowiadania. Tę formę wypowiedzi gimnazjaliści uznali za dużo łatwiejszą. Prawdopodobnie opinia taka spowodowana była świadomością własnych trudności w konstruowaniu tekstów o odpowiedniej strukturze ${ }^{47}$.

Problemy rosną wraz z wiekiem uczniów. Według badaczy języka młodzieży, Jacka Warchali i Aldony Skudrzykowej,

Młode pokolenie Polaków z coraz większym trudem radzi sobie z tekstem pisanym, a kłopot $\mathrm{z}$ jego poprawnym sformułowaniem mają nawet ci, którzy już wkrótce będą takich umiejętności uczyć w szkole - studenci polonistyki. Nawet wśród nich ujawniają się tacy, u których zaobserwować można w różnym stopniu natężenia oznaki analfabetyzmu funkcjonalnego, przejawiającego się w tym, że w pisanych przez nich tekstach załamuje się logika zdań, brak jest jednej linii prowadzenia tematu; zachwiana jest spójność zarówno w sferze kohezji, czyli spójności gramatycznej, jak i koherencji. Zachwiana zostaje logika na poziomie tekstu, bo myśl nabiera spójności jedynie wówczas, gdy włączymy naszą potoczną wiedzę i znajomość konkretnych okoliczności, o jakich tekst mówi lub w jakich tekst powstał ${ }^{48}$.

W związku z pogłębiającym się problemem w opanowaniu umiejętności stanowiącej istotną część kompetencji komunikacyjnej natychmiast rodzi się pytanie o to, czy w tej sytuacji nie grozi tu reprodukcja trudności w tworzeniu tekstów pisanych i ich rozumieniu. Trudno jest uczyć umiejętności, która wcześniej samodzielnie nie została opanowana. Sposób nauczania jest kształtowany pod wpływem sposobu egzaminowania. W wyniku nauki „pod test” uczniowie coraz lepiej odnajdują się w meandrach testowych podchwytliwości, a coraz trudniej jest im napisać choćby krótki, rzeczowy, spójny i poprawny tekst.

\section{Podsumowanie}

Sprawne korzystanie z kodu językowego daje poczucie pewności, dzięki któremu $\mathrm{z}$ większą swobodą, precyzją i indywidualnym stylem wyrażane są

47 Osobną kwestię stanowi fakt, na który zwrócił uwagę T. Zgółka - w polskiej szkole nadal na języku polskim dominuje gatunek rozprawki, podczas gdy na lekcjach innych języków polski uczeń pisze esej (argumentacyjny). Być może nadszedł czas na dokonanie rewizji dotychczasowych form wypowiedzi?, por. T. Zgółka, op. cit., s. 78.

${ }_{48}$ J. Warchala, A. Skudrzyk, Kultura piśmienności młodego pokolenia, Oficyna Wydawnicza WW, Katowice 2010, s. 7 . 
myśli. Przez pryzmat języka człowiek postrzega otaczający świat, ale również w języku człowiek wyraża własne przemyślenia, przeżycia, emocje. Wysoka kompetencja komunikacyjna jest doskonałym polem autoprezentacji. Język, jakim posługujemy się na co dzień lub sposób przekazu wybrany przez nadawcę w konkretnej sytuacji komunikacyjnej, jest jednym z najistotniejszych elementów jego autoprezentacji i jego oceny przez odbiorców. Innymi słowy, prezentujemy się, komunikując. Przekazując jakąkolwiek treść, nadawca komunikatu jednocześnie bardzo wiele mówi o sobie samym. Dysponując wysoką kompetencją komunikacyjną, nadawca może ponadto świadomie wybrać odpowiednie dla danej sytuacji środki językowe i w zależności od rozmówców bądź sytuacji komunikacyjnej zaprezentować się albo jako erudyta, albo dobry kumpel, albo przyjąć inne dowolnie wyznaczone sobie role.

Większość myśli ma charakter językowy. Ludwig Wittgenstein napisał: „granicę [myśleniu] wytycza się tylko w języku, a co poza nią, będzie po prostu niedorzecznością"49. Uświadomienie sobie pewnych niezwerbalizowanych dotąd intuicji, przeczuć, wrażeń następuje wówczas, gdy postaramy się je nazwać, choćby sami dla siebie. Dlatego też język ubogi, prostacki wiele mówi o sposobie myślenia jego użytkownika, a język bogaty, stosowany odpowiednio do sytuacji, komunikatywny, staranny, świadczy, ale i „poszerza” granice świata jego właściciela. Jest doskonałym narzędziem głębszych refleksji, bez którego byłyby one niezwykle utrudnione. Wzbogacanie własnego języka poszerza więc horyzonty myślowe ${ }^{50}$. Wysoka kompetencja komunikacyjna ułatwia społeczne interakcje, niska - może nawet prowadzić do izolacji.

Język i komunikacja werbalna są także podstawowymi elementami kultury ludzkiej. Bez nich żadna kultura nie mogłaby istnieć. W języku zawiera się dorobek kulturowy pewnej społeczności, będący zarazem magazynem informacji o rzeczywistości, w której ta społeczność egzystowała i egzystuje. Jako narzędzie komunikacji wiąże się on z umową społeczną. "Umawiamy się" co do znaczenia poszczególnych słów, stosowania konstrukcji gramatycznych, zasad kultury języka. Jest to jednak narzędzie niezwykle ciekawe, wchodzące w różnorodne zależności, żywo reagujące na zmiany społeczne, ewoluujące wraz z upływem czasu i w ten sposób zmieniające oblicze kultury czy też ją

49 L. Wittgenstein, Tractatus logico-philosophicus, przekł. B. Wolniewicz, PWN, Warszawa 1997, s. 3 .

50 Ta kwestia bardzo silnie wiąże się z hipotezą Sapira-Whorfa, która mówi o ścisłej zależności myślenia i języka. Jej sformułowanie rozpoczęło falę niezwykle interesujących badań, których celem było potwierdzenie bądź obalenie tej hipotezy. Przywołanie ich wykracza poza ramy tematyczne artykułu. Obecnie jednak wiadomo, że choć zależność ta nie jest bezwzględna, to wyraźny związek myślenia i języka jest już faktem bezspornym. 
samą. Utworzenie nowych terminów dla nazwania pojawiających się zjawisk, nie mówiąc już o nazwach urządzeń technicznych, świadczy przecież dobitnie, że takie zjawiska powstały i są zauważane przez społeczeństwo. Język jest więc lustrem życia społecznego. Im wyższa kompetencja komunikacyjna w zakresie danego języka, tym większa możliwość skorzystania z tej wiedzy.

Wydaje się, że powyższe powody są wystarczające, by zadbać o szczególną pomoc w rozwijaniu wysokich umiejętności językowych przez dzieci i młodzież. Te, które je osiągną, są postrzegane jako zdolne, inteligentne, otrzymują wyższe oceny. Pozytywne komunikaty ze strony nauczyciela ośmielają je, a ponieważ nie mają kłopotu z wypowiedzią, częściej zabierają głos, przez co intensywnie się uczą. W efekcie, ci właśnie uczniowie w praktyce szkolnej są grupą bardziej uprzywilejowaną - wśród „równych” oni są „równiejsi”. Zazwyczaj jest to wynik odpowiedniej stymulacji, jaka została im zapewniona we wczesnym dzieciństwie $\mathrm{w}$ domu rodzinnym. W tym miejscu rodzi się pytanie: Co z pozostałymi? Odpowiednio poprowadzona edukacja szkolna mogłaby stanowić dla nich doskonałe pole rozwoju umiejętności językowych. Niestety, sposób organizacji procesu kształcenia, praktyka edukacyjna, nadmierne uwikłanie szkoły w testomanię sprawiają, że jest to $\mathrm{w}$ wielu przypadkach niewykorzystana szansa.

Powszechność stosowania testów w praktyce edukacyjnej w połączeniu z aktualnymi tendencjami panującymi we współczesnej polszczyźnie skrótowością, ikonizacją, emocjonalizacją przekazu, upowszechnianiem się „mowy zapisanej” w miejsce tekstu pisanego, a także naciskiem w komunikacji na odbiorcę, a nie nadawcę ${ }^{51}$ powodują ogromne trudności w kształtowaniu się kompetencji komunikacyjnej, stanowiącej istotny kapitał społeczno-kulturowy młodego człowieka. Ci, którzy potrafią w sposób jasny, klarowny, adekwatny do sytuacji przekazać własne myśli, częściej niż inni mają odwagę, żeby przedstawić swoje racje i zwykle postrzegani są jako ci, którzy rację mają. Stopień opanowania kompetencji komunikacyjnej tworzy więc grupę "równych i równiejszych”, a obciążenie nauki balastem testomanii utrudnia pomoc tym dzieciom, które jej szczególnie potrzebują, tworząc tym samym swoisty edukacyjny paradoks.

${ }_{51}$ J. Warchala, Myszka to manipulator stołokulotoczny, „Dziennik. Gazeta Prawna” z 16-18 stycznia 2015 r., s. 2. 


\section{BIBLIOGRAFIA}

Austin J. L., Mówienie i poznawanie. Rozprawy i wykłady filozoficzne, przekł. B. Chwedeńczuk, PWN, Warszawa 1993.

Bernstein B., Odtwarzanie kultury, przekł. Z. Bokszański, A. Piotrowski, PIW, Warszawa 1990.

Bielecka-Prus J., Transmisja kultury w rodzinie iw szkole. Teoria Basila Bernsteina, PWN, Warszawa 2010.

Bochno E., Rozmowa jako metoda oddziaływania wychowawczego, Oficyna Wydawnicza Impuls, Kraków 2004.

Eriksen T. H., Tyrania chwili. Szybko i wolno plynący czas w erze informacji, przekł. G. Sokół, PIW, Warszawa 2003.

Górnikowska-Zwolak E., Język ojczysty - zaniedbany obszar wychowania, „Kultura i Społeczeństwo" 2010, $\mathrm{nr} 2$.

Grabias S., Język w zachowaniach społecznych, Wydawnictwo Uniwersytetu Marii Curie-Skłodowskiej, Lublin 1997.

Hymes D., Socjologia i etnografia mówienia, przekł. K. Biskupski, [w:] Język i społeczeństwo, M. Głowiński (red.), Czytelnik, Warszawa 1980.

Klus-Stańska D., Nowicka M., Sensy i bezsensy edukacji wczesnoszkolnej, WSiP, Warszawa 2005.

Kurcz I., Dwujęzyczność a język globalny, [w:] Problemy współczesnej dydaktyki języków obcych, M. Pawlak, M. Derenowski, B. Wolski (red.), Wydawnictwo Uniwersytetu im. Adama Mickiewicza, Poznań - Kalisz 2009.

Levi-Strauss C., Kultura i język, przekł. J. Trznadel, [w:] Antropologia słowa, G. Godlewski, A. Mencwel, R. Sulima (red.), Wydawnictwo Uniwersytetu Warszawskiego, Warszawa 2003.

Lyons J., Semantyka, t. 2, przekł. A. Weinsberg, PWN, Warszawa 1989.

Magdulka i cały świat. Rozmowa biograficzna $z$ Witoldem Kieżunem przeprowadzona przez Roberta Jarockiego, ISKRY, Warszawa 2013.

Marcjanik M., Grzeczność w komunikacji językowej, PWN, Warszawa 2013.

Nowy słownik gwary uczniowskiej, H. Zgółkowa (red.), Europa, Wrocław 2004.

Ong W. J., Oralność i piśmienność. Słowo poddane technologii, przekł. J. Japola, Wydawnictwo Uniwersytetu Warszawskiego, Warszawa 2011.

Puzynina J., Język w życiu społecznym i rodzinnym, „Poradnik Językowy” 1996, październik, z. 8.

Ravitch D., Testy precz ze szkół!, „Gazeta Wyborcza” z 6-7 grudnia 2014 r.

Sawicka G., Konwencja a kompetencja komunikacyjna, [w:] Język w komunikacji (1), G. Habrajska (red.), Wydawnictwo Wyższej Szkoły Humanistyczno-Ekonomicznej w Łodzi, Łódź 2001.

Skudrzykowa A., Czy zmierzch kultury pisma? O synestezji i analfabetyzmie funkcjonalnym, Wydawnictwo Uniwersytetu Śląskiego, Katowice 2005.

Smółka L., Kompetencja komunikacyjna dzieci sześcio-siedmioletnich, Wydawnictwo Naukowe Akademii Pedagogicznej, Kraków 2004.

Warchala J., Myszka to manipulator stołokulotoczny, „Dziennik. Gazeta Prawna” z 16-18 stycznia $2015 \mathrm{r}$.

Warchala J., Skudrzyk A., Kultura piśmienności młodego pokolenia, Oficyna Wydawnicza WW, Katowice 2010.

Wittgenstein L., Tractatus logico-philosophicus, przekł. B. Wolniewicz, PWN, Warszawa 1997.

$Z$ badań nad kompetencja komunikacyjna dzieci, B. Bokus, M. Haman (red.), Energeia, Warszawa 1992.

Żytko M., Pozwólmy dzieciom mówić i pisać - w kontekście badań językowych trzecioklasistów, CKE, Warszawa 2010. 
http://www.operon.pl/wyniki_ogolnopolskie_probny_sprawdzian_szostoklasisty. http://cke.edu.pl/images/files/gimnazjum/wstepna_informacja_o_wynikach/2014/20140616_ GIMNAZJUM_Wst\%C4\%99pna_informacja_o_wynikach_2014r.pdf.

http://www.bc.ore.edu.pl/Content/232/Tom $+2+J \% C 4 \% 99 z y k+$ polski+w+szkole+podstawowej $\% 2 \mathrm{C}+$ gimnazjum+i+liceum.pdf.

\section{SUMMARY}

\section{The Equal and the More Equal.}

\section{Communicative Competence and Educational Paradoxes}

Communicative competence is the ability to use language adequately in each communicative situation. Apart from linguistic competence, which allows the user to build grammatically and semantically correct utterances, it also includes cultural knowledge relating to the social context, in which language is used. A high level of communicative competence is an important element of the presentation of the message sender, which enhances and facilitates interpersonal contacts and enables a more extensive use of the knowledge accumulated in the language by the cultural community.

The purpose of this article is to define communicative competence and to provide examples of educational practice which question the supportive role of schools in developing children's language skills.

KEY WORDS: communicative competence, linguistic competence, inequality, linguistic communication. 